\title{
A Preliminary Study on the Positive Competition Mechanism "Promoting the Reform, Enhancing the Learning and Improving the Quality of Teaching by Competition Participating" of Animation Major in Higher Vocational Colleges
}

\author{
Yefen Zheng ${ }^{1, a^{*}}$, Boxia Zeng ${ }^{1, b}$ and Laiquan Liu ${ }^{1, c}$ \\ ${ }^{1}$ No.128, Fuhai Road Qionghai, Hainan, PRC \\ a652662287@qq.com, b9080668@qq.com, mail.sea@qq.com
}

\section{Keywords: School-Enterprise; Animation; Mechanism; Competition; Quality of teaching}

\begin{abstract}
The paper analyzes the current situation of professional animation competition, professional construction, course teaching and project training and puts forward some measures and methods to construct the positive competition mechanism "promoting the reform, enhancing the learning and improving the quality of teaching by competition participating" based school-enterprise integration through the combination of the author's much experience in organizing and guiding the animation competitions in HAINAN College of Software Technology.
\end{abstract}

\section{Introduction}

In recent years, to enhance the quality of personnel training through various competitions in higher vocational colleges has been recognized and praised highly by the vocational education sector. The teachers and researchers in higher vocational colleges have involved in the research and practice of "promoting the reform, enhancing the learning and improving the quality of teaching by competition participating", which makes great achievements. All levels of government and industry organizations also advocate competitions actively at all levels, in order to effectively enhance the quality of personnel training in higher vocational colleges and the cooperation between vocational colleges and enterprises, associations and others.

The positive roles of "promoting the reform, enhancing the learning and improving the quality of teaching by competition participating" in the professional construction of vocational colleges, curriculum teaching and student skills training and other aspects are beyond all doubt. However, some vocational colleges isolate the competitions with professional construction, curriculum teaching and student skills training only make efforts for the competitions while ignoring their functions in the professional development, curriculum teaching and student skills training, which will inevitably affect the quality of personnel training and decline students employment.

\section{Current Situation and Urgent Problems of Animation Major Competition in Higher Vocational Colleges}

Various Levels of Animation Competitions, Teachers and Students Accepting the Battle in Haste. Many domestic vocational colleges have set up animation and related majors as the national policies continuously support the development of cultural industries, including animation-related competitions jointly organized by the government, industries and associations. Higher vocational colleges spare no effort to participate in various competitions to enhance their visibility and professional competitiveness, however, too many competitions, the lack of competition experience and the corresponding long-term mechanism and hasty preparations have led to the tiredness and non-confidence of teachers and students.

Cultivating Talents for the Competition Alone and Losing the Greater for the Less. At present, the provincial and the national occupation skill competition are highly praised by vocational colleges, which have become an important benchmark for the quality of personnel training. In order to obtain good results in these two levels of competition, many vocational colleges 
take this opportunity to increase the professional reform efforts and introduce school-enterprise cooperation mechanism; however, some institutions only bring the reform benefits to individual students. They select excellent students to carry out training or arrange them directly to the enterprise, who only pursue the high-grade, but ignore the promotion roles of competitions for all students' professional skills. They only make those excellent students stand out in the national occupation skill competition, not knowing the original level of other students and ignoring the practical significance of the skills. "Enhancing the learning by competition participating" only reflects in someone, not all students, which will cause the negative operation of "promoting the reform, enhancing the learning and improving the quality of teaching by competition participating" mechanism.

Skills of the Competition Students Unable to Meet the Enterprise Demand. The purpose of vocational skills competition is to emphasize the practicality and mobilize enterprises into the campus, teachers and students into the enterprises, while the aim of the government inviting industry experts to participate in the proposition or evaluation of the competition is to let enterprises examine whether the quality of talents training can meet their demands and promote the exchanges and cooperation between schools and enterprises. However, part of the school-enterprise cooperation is just the form due to their shallow cooperation. As the counselors lack practical experience in business and do not understand the enterprise employment standards, the operating norms developed in the skills competition are not in line with the actual operation of the enterprises, making rules of the competition lose the meaning and students' skills unable to be recognized by enterprises and improve their professional skills, which certainly result in the employment gap in animation personnel training and its market and even the poor applicability of their employment.

\section{Construction Methods of Positive Competition Mechanism "Promoting the Reform, Enhancing the Learning and Improving the Quality of Teaching by Competition} Participating"

Integrate the Competition Mechanism into Professional Construction to Achieve "Promoting the Reform by Competition Participating". Professional reform is the guarantee of professional personnel training. All kinds of competitions are the "engine" to promote the professional reform of higher vocational colleges, which take the competition as the link, intensify school-enterprise integration, continue to learn from the enterprises and jointly develop personnel training programs and curriculum system. Various competition programs are developed by the enterprise staff based on market demand for talent standards, representing the general requirements. Therefore, the professional construction in vocational colleges should broaden the channels to introduce enterprises, arrange professional teachers to enterprises to participate in project training, familiar with the enterprise industry standards, and construct professional training base, professional training room with the enterprises and bring them into the classroom, plan professional curriculum system with the enterprise production process, take the enterprise's employment standards as the evaluation criteria for professionals, absorb the enterprise's management model to strengthen the job responsibility for professionals. After few years of construction, HAINAN College of Software Technology's animation major has establish cooperative relationships with a number of enterprises inside and outside the province and sent nearly 20 professional teachers to receive the enterprise training. Under the guidance of the enterprises, HAINAN College of Software Technology has established the modular curriculum system, closely matched the competition requirements and made reasonable arrangements for the courses, making the backbone of enterprises lead students to participate in professional training and letting all professional students enjoy the teaching results brought about by the competition. At present, HAINAN College of Software Technology's animation major has been the characteristic key specialty in Hainan Province, provincial backbone specialty and completed a number of provincial and college-level teaching reform projects.

Integrate the Competition Standard into the Course Teaching to Achieve "Improving the Quality of Teaching by Competition Participating". Curriculum teaching is an important link of 
professional construction program. The teaching of vocational education should pay special attention to the relationship between "teaching" and "learning" and teachers should focus on "how to teach" and "what to teach" and the innovation of teaching organization forms. Vocational skill competition puts forward a new topic for higher vocational education, so the animation major of HAINAN College of Software Technology constructs "professional construction platform, curriculum construction platform, curriculum teaching platform" talent training mode, especially the curriculum teaching platform requires teachers to seriously comprehend the spirit of all competitions, carefully grasp the requirements and carry out teaching activities. This model effectively regulates the teaching behavior of teachers and prompts teachers to continuously upgrade their professional quality. Several teachers of HAINAN College of Software Technology have won the first prize with their strong professional quality in the teaching competitions between vocational colleges in Hainan Province.

Integrate the Competition Projects into the Training Activities to Achieve "Enhancing the Learning by Competition Participating". Project-based teaching has always been the reform focus of animation major in HAINAN College of Software Technology. Also all animation professional teachers need to simulate a number of projects and introduce them into the practical teaching activities according to each competition. The course training is to carry out the competition in the form of small projects, while the integrated training is to carry out the competition in the form of big projects. This teaching method to integrate the competition into the teaching activities can drive students' independent professional skills learning and active practice, greatly arousing the enthusiasm of professional learning, enhancing the interest of students and building their confidence and achieving the "competition-teaching win - win".

\section{Conclusion}

The paper analyzes the problems in the competition organization of vocational colleges and universities based on the author 's many years of experience in organizing and participating in various types of animation competitions, summarized their causes, puts forward some measures to implement the competition mechanism through the trial and effectiveness of the positive competition mechanism "promoting the reform, enhancing the learning and improving the quality of teaching by competition participating" and the example of animation major, which is to form a personnel training long-term mechanism "promoting the reform, enhancing the learning and improving the quality of teaching by competition participating" in higher vocational colleges through the combination of the competition mechanism and the professional construction, the combination of the competition and project training, and the combination of the competition and the course teaching.

\section{Acknowledgements}

This paper is one of the phased achievements of the higher education teaching reform project in Hainan the research and practice of school-enterprise integration and industry-academy cooperation talents training model--taking animation profession as an example” (Hnjg2016-75).

\section{References}

[1] Xue Min. Exploration on the Teaching Mode of "Promoting Learning and Teaching by Competition Participation" Based on the Animation Major of the Enterprise and Practice Base [J].Journal of Shanxi Coal-Mining Administrators College,2016,29(1):149-151.

[2] Yang Fan, Zhang Yaohua, Xu Xuemei .A Study on Promoting Teaching and Learning by Competition Participation in the Higher Vocational Colleges [J],Management \& Technolosy of SME, 2015(6):275-276. 
[3] Wang Qian. An Analysis on Demonstrating Mechanism of Higher Vocational Software Technology Major Skill Competition "Promoting the Reform, Enhancing the Learning and Improving the Quality of Teaching by Competition Participating" [J], Computer Knowledge and Technology, 2015, 11(17):123-125.

[4] Shi Xumei. The Establishment of English Teaching Mechanism--"Promote Learning by Competition and Improvement by Learning" in Oral Contest of Higher Vocational Education [J],Journal of Taiyuan Urban Vocational College, 2015(10):73-74.

[5] Xu Chong. An Study on the Importance of the Teaching Mode of "Promoting the Learning and Teaching by Competition Participation, and the Combination of Competition and Learning" for Art Design Students [J], Cultural and Educational Research, 2016,(19):257. 